\title{
Reanimatieonderwijs in Nederland
}

\section{Bijeenkomst NVMO-werkgroep PMO 14 maart 2007. UMC Utrecht, Vergadercentrum, AZU zaal 2, 14.15-17.00 uur}

Onderwijs in acute zorg is momenteel onderwerp van landelijk belangstelling.1-3 Toegespitst op het reanimatieonderwijs wil de NVMO-werkgroep Practisch Medisch Onderwijs (PMO) daar op 14 maart 2007 aandacht aan besteden. Op welke wijze wordt er op elke faculteit aandacht besteed aan het onderwijs in reanimatievaardigheden, waar en hoe in het curriculum komt het aan bod, hoe vindt integratie met het theoretisch onderwijs plaats, wie verzorgt dit onderwijs, gebeurt het ook in de coschappen, hoe wordt op elke faculteit omgegaan met de veranderende richtlijnen van de Nederlandse ReanimatieRaad (NRR), hoe wordt geëxamineerd, krijgen onze studenten ook een certificaat, is het tijd voor landelijke afstemming? Deze vragen komen aan de orde aan de hand van een presentatie van het reanimatieonderwijs aan de Medische Faculteit van de Universiteit Maastricht.

De werkgroep PMO stelt zich ten doel om locale ervaringen op het gebied van het practisch medisch onderwijs interfacultair uit te wisselen. Dit keer dus over het onderwijs in reanimatievaardigheden. Graag nodigen we alle betrokken bij dit onderdeel van het vaardigheidsonderwijs uit om deel te nemen aan deze bijeenkomst van de werkgroep PMO. Opgave via: www.nvmo. $\mathrm{nl}$ (onder: 'Mededelingen').

\section{Literatuur}

Severien I, Tan ECTH, Metz JCM, Biert J, Berden HJJM. Het niveau van eersthulpverlening en basale reanimatie door aankomende artsen. Ned Tijdschr Geneeskd 2005;149(31):1756-7.

Nooij J de. Onvoldoende kwaliteit thoraxcompressies: hulpverleners kunnen niet voldoen aan nieuwe reanimatierichtlijnen. Med Contact 2006;61(33/34):1310-1.

Draaisma JMTh, Roets G, Kesteren RG van, Vulto A, mede namens de comissie spedeisende geneeskunde VVAA. Inventaristatie van het onderwijs in de spoedeisende geneeskunde in de opleiding tot basisarts in Nederland. Tijdschrift voor Medisch Onderwijs 2006;25(3):117-24. 